\title{
Zinc, copper, or cerium accumulation from metal oxide nanoparticles or ions in sweet potato: Yield effects and projected dietary intake from consumption
}

Scott Bradfield ${ }^{1}$, Pawan Kumar ${ }^{1}$, Jason C. White ${ }^{2}$, and Stephen Ebbs ${ }^{1}{ }^{*}$

Running head: Accumulation of metals from metallic oxide nanoparticles and ions in sweet potato tubers 


\section{Abstract}

16 The potential release of metallic oxide engineered nanoparticles (ENP) into agricultural systems

17 has created the need to evaluate the impact of these materials on crop yield and food safety. The

18 study here grew sweet potato (Ipomoea batatas) to maturity in field microcosms using substrate

19 amended with three concentrations $\left(100,500\right.$ or $\left.1,000 \mathrm{mg} \mathrm{kg} \mathrm{DW}^{-1}\right)$ of either $n \mathrm{ZnO}, n \mathrm{CuO}$, or

$20 n \mathrm{CeO}_{2}$ or equivalent amounts of $\mathrm{Zn}^{2+}, \mathrm{Cu}^{2+}$, or $\mathrm{Ce}^{4+}$. Adverse effects on tuber biomass were

21 observed only for the highest concentration of $\mathrm{Zn}$ or $\mathrm{Cu}$ applied. Exposure to both forms of $\mathrm{Ce}$

22 had no adverse effect on yield and a slight positive benefit at higher concentrations on tuber

23 diameter. The three metals accumulated in both the peel and flesh of the sweet potato tubers,

24 with concentrations higher in the peel than the flesh for each element. For $\mathrm{Zn},>70 \%$ of the

25 metal was in the flesh and for $\mathrm{Cu}>50 \%$. The peels retained 75 to $95 \%$ of $\mathrm{Ce}$ in the tubers. The

26 projected dietary intake of each metal by seven age-mass classes from child to adult only

27 exceeded the oral reference dose for chronic toxicity in a scenario where children consumed

28 tubers grown at the highest metal concentration. The results throughout were generally not

29 different between the ENP- and ionic-treatments, suggesting that the added ENPs underwent

30 dissolution to release their component ions prior to accumulation. The results offer insight into

31 the fate and impact of these ENPs in soils.

33 Author keywords: Nanoparticles, Nanomaterials, Metals, $\mathrm{ZnO}, \mathrm{CuO}, \mathrm{CeO}_{2}$, Sweet potato 


\subsection{Introduction}

Nanotechnology is developing rapidly into a trillion-dollar industry [1]. One facet of this industry involves the production of engineered nanoparticles (ENPs), a material with at least two dimensions between 1 and $100 \mathrm{~nm}$. Nanoparticles often display properties different than their bulk (>100 $\mathrm{nm}$ in at least two dimensions) or ionic counterparts due to their composition, surface properties, and high surface to volume ratio. Metallic nanoparticles such as $\mathrm{ZnO}, \mathrm{CuO}$, and $\mathrm{CeO}_{2}$ are among the most common materials in commercial use due to their numerous applications. Nanoparticles of $\mathrm{ZnO}(n \mathrm{ZnO})$ have uses in personal care products like sunscreens as well as applications in catalysis, chemical manufacturing, optical devices, and biosensors [2]. For $\mathrm{CuO}$ nanoparticles $(n \mathrm{CuO})$, there are uses as an antimicrobial agent, in chemical catalysis,

44 and in a variety of products such as inks, ceramics, lubricants, and electronics [3]. Nanoparticles of $\mathrm{CeO}_{2}\left(n \mathrm{CeO}_{2}\right)$ have applications in fuel catalysis, paints and $\mathrm{UV}$-protectant coatings, or electrolytic processes [4].

7

$$
\text { The rapid expansion of nanoparticle use has raised concerns about their prospective }
$$
release into agricultural systems through application of biosolids or nano-functionalized agrochemicals and the potential impact of these engineered materials on crop plants and food safety. A wide variety of studies have been conducted with crop plants to examine the toxicity of metallic nanoparticles [for reviews, see 5, 6-9]. Many of these studies have been conducted under idealized conditions, such as in hydroponics or soilless media, and over relatively short periods of time. The primary goals of these studies have been to assess the physiological effects 54 of the nanomaterials and determine their inherent toxicity. Additional studies have considered 55 the genotoxicity of ENPs to plants [10-13] or used-omic technologies to determine how ENPs 56 influence gene and protein expression [14-18]. More recently, some studies have examined the 
57 influence of exposure during the entire life cycle [4, 19-22]. Such studies provide a much

58 needed perspective on the impact on yield of agricultural crops and not just the short-term

59 physiological effect on growth. The resulting accumulation of metals from metallic oxide ENPs

60 such as $n \mathrm{ZnO}, n \mathrm{CuO}$, and $n \mathrm{CeO}_{2}$ have also been reported in these studies, providing information

61 useful in determining the potential impact of ENPs on the safety of the edible plant tissues.

62 To provide additional information on the influence of metallic oxide nanoparticles on the

63 yield of an agricultural crop, the present research compared the impact of three materials in

64 nanoparticle $\left(n \mathrm{ZnO}, n \mathrm{CuO}\right.$, or $\left.n \mathrm{CeO}_{2}\right)$ or ionic form $\left(\mathrm{Zn}^{2+}, \mathrm{Cu}^{2+}\right.$, or $\left.\mathrm{Ce}^{4+}\right)$ on the yield of sweet

65 potato (Ipomoea batatas (L.) Lam). These nanomaterials were selected because they represent

66 three of the ten most commonly used nanomaterials [23]. The ionic forms of each metallic

67 nanoparticle, added in parallel pots at the equivalent concentration of $\mathrm{Zn}, \mathrm{Cu}$, or $\mathrm{Ce}$, were

68 included for comparison. Sweet potato was the crop species examined because it is the third

69 most common starchy root crop and the seventh most important crop globally [24]. There have

70 been no prior studies with nanomaterials and this plant species. The sweet potato tuber has an

71 outer "peel" that can be consumed hence the potential accumulation of metals in this layer has

72 implications for food preparation and food safety. For example, the outer cell layer of carrot

73 (Daucus carota) was shown recently to retain a large fraction of metals from a similar exposure

74 regime of nanoparticle or ionic $\mathrm{Zn}, \mathrm{Cu}$, or $\mathrm{Ce}$ [25]. Removal of this layer greatly reduced the

75 projected dietary exposure to these metals that might result from consumption [26]. A similar

76 question was addressed here, estimating dietary intake of $\mathrm{Zn}, \mathrm{Cu}$, or $\mathrm{Ce}$ that might occur from

77 the consumption of sweet potato (with or without the tuber peel) grown under each metal

78 exposure regime. The overarching goal of this study was to provide insight into the potential

79 fate, effect, and risk of these metal oxide nanomaterials in agricultural systems. 


\subsection{Materials and Methods}

2.1 Microcosm experiment

Sweet potato (Ipomoea batatas var. Georgia Jet) plants were obtained as slips $(30-35 \mathrm{~cm}$ in length) from New Hope Seed Company (Bon Aqua, TN). The slips were separated and planted temporarily in pots of Fafard 3B mix (Hummerts International, St. Louis, MO) until the nanoparticle-treated soils were prepared. During this growth period, the pots with the sweet potato slips were maintained under natural outdoor conditions (ambient light, natural precipitation with supplementary tap water as needed to maintain hydration). Plants for the $\mathrm{Zn}$-, $88 \mathrm{Cu}-$, and $\mathrm{Ce}$-treated pots were grown under these conditions for 7, 9, and $16 \mathrm{~d}$ respectively. A minimum of one week of growth in the potting mix was allowed for the plants to acclimate and resume root growth. However, as it was not possible to establish all the microcosms for all three elements on the same day, the experiment was set up at intervals by metal in the order listed above. That is, the microcosms for the $\mathrm{Zn}$ treatment were established $7 \mathrm{~d}$ after the slips were planted in the potting mix, those for $\mathrm{Cu} 2 \mathrm{~d}$ later, and those for $\mathrm{Ce}$ one week later. These intervals were needed to allow sufficient time to establish all the treatments and replicates for

95 each metal. The experiment design was not intended to make comparisons between the metal treatments so the logistical necessity of this planting schedule was utilized. substrate suitable for sweet potato propagation. After mixing, $3 \mathrm{~kg}$ of the substrate mix was 99 placed into a plastic pot and amended with 10-30-20 fertilizer along with supplemental $\mathrm{KCl}$ to 100 provide final NPK application rates of $67.3,201.8$, and $201.8 \mathrm{~kg} \mathrm{ha}^{-1}$, respectively. Each plastic 101 pot was seated on top of a 18.9 L bucket, providing a microcosm structure that allowed free flow 102 of soil water through the pot to collect in the bucket. This approach was used to prevent 
103 accumulation of excess water in the rhizosphere that would adversely affect sweet potato growth.

104 Throughout the experiment, any discharge into the bucket was watered back into the pot to 105 preclude losses of fertilizer or the amended treatments.

106 Three nanoparticle suspensions were obtained from US Research Nanomaterials, Inc.

107 (Houston, $\mathrm{TX}): \mathrm{ZnO}(30-40 \mathrm{~nm}), \mathrm{CuO}(25-55 \mathrm{~nm})$, and $\mathrm{CeO}_{2}(30-50 \mathrm{~nm})$. All suspensions were

108 at least $99 \%$ purity. Aliquots were withdrawn from the nanoparticle stock suspension and

109 diluted in deionized water to a total volume of $2 \mathrm{~L}$. These solutions were opaque due to the high

110 concentration of nanoparticles, limiting the utility of dynamic light scattering to collect data on

111 the nanoparticles. These working stock suspensions were used to immediately treat the

112 microcosms so the characteristics of the nanoparticles would have immediately changed upon

113 addition to the soil. The ENPs were introduced to the $3 \mathrm{~kg}$ of soil by mixing the $2 \mathrm{~L}$ of the

114 respective working stock suspension with the soil until evenly wetted. The corresponding

115 solutions of ionic $\mathrm{Zn}, \mathrm{Cu}$, and $\mathrm{Ce}$ were prepared by dissolving the required mass of the sulfate

116 salts in deionized water and amending them in the same manner as the ENP solutions. The final

117 treatment concentrations in the substrate were 100,500 , and 1,000 $\mathrm{mg} \mathrm{kg} \mathrm{DW}^{-1}$ of $\mathrm{Zn}, \mathrm{Cu}$, or $\mathrm{Ce}$.

118 The volume of water added brought the soil to $\sim 80 \%$ of field capacity. The soils were allowed to

119 equilibrate indoors under ambient conditions for $48 \mathrm{hr}$. Sweet potato slips were transplanted

120 from the temporary pots to an ENP or ionic treated pot (one plant per pot) by placing the bottom

121 of the slip $10.5 \mathrm{~cm}$ into the soil and then lightly packing the soil around the plant stem. Plants

122 were grown under conditions of natural sunlight, temperature, and precipitation for 130 days.

123 Supplemental tap water was added as needed to maintain soil hydration. Any water flowing

124 through the pots was irrigated back into the pot during this time. 
At harvest, the tubers were recovered from the pots and immediately brushed to remove 126 adhering soil particles. The tubers were allowed to cure by being placed in brown paper bags

127 and kept in a phytotron at $18-22^{\circ} \mathrm{C}$. Once the potatoes had cured for at least $15 \mathrm{~d}$, the tubers

128 were rinsed with deionized water and lightly scrubbed with a brush to clean the tuber surface.

129 While this may not have achieved complete removal of adhering soil particles, the goal was to

130 emulate a typical harvesting procedure. One tuber free from cracks or defects of at least $9 \mathrm{~cm}$ in

131 length, $5 \mathrm{~cm}$ in diameter, and $118 \mathrm{~cm}^{3}$ in volume, corresponding to U.S. Extra No. 1 grade, was

132 selected from each harvested pot for analysis. Each of these tubers was cut into quarters along

133 the horizontal axis. Two of the quarters were peeled while the other two were not peeled. All of

134 the quarters were then cut into pieces no bigger than $0.5 \mathrm{~cm}$. Half of the tuber (one quarter

135 peeled and one quarter not peeled) were dried to constant mass at $65^{\circ} \mathrm{C}$. The other half of the

136 tuber was placed in a $-80^{\circ} \mathrm{C}$ freezer for storage and subsequent study. Samples for elemental

137 analysis were subjected to acid digestion according to USEPA method 3050b [27] and analysed

138 for Zn or $\mathrm{Cu}$ using a SpectrAA 220FS Atomic Absorbance Spectrometer (Varian Inc., Palo Alto,

139 CA) or for Ce using inductively coupled plasma mass spectroscopy (ICP-MS, Agilent 7500ce, 140 Santa Clara, CA).

\subsection{Dietary intake modeling for $\mathrm{Zn}, \mathrm{Cu}$, or Ce}

The modeling of dietary intake utilized the fresh weight tissue concentration of $\mathrm{Zn}, \mathrm{Cu}$, or

144 Ce. The fresh weight concentration was back-calculated using the dry weight concentration and

145 the percent water content of the tuber tissue. Human dietary intake was calculated using the

146 following formula [28, 29], where dietary intake is expressed in units of $\mu \mathrm{g} \mathrm{kg}^{-1} \mathrm{~d}^{-1}$, tissue 
147 concentration is in $\mathrm{mg} \mathrm{kg} \mathrm{FW}{ }^{-1}$, mass consumed and body mass are both in kilograms, and a 148 conversion factor of 1,000 is included to adjust the units from milligrams to micrograms.

$$
\text { dietary intake }=\frac{\text { tissue concentration } \times \text { mass per serving } \times \text { \#of servings } \times 1,000}{\text { body mass }}
$$

152 exposed either to the nanoparticle or the corresponding ion. The mass per serving of sweet

153 potato $(0.114 \mathrm{~kg})$ was derived from the USDA Food and Nutrition Service

154 (http://www.fns.usda.gov/sites/default/files/HHFS_SWEET\%20POTATOES_FRESH_Dec\%202

155 012.pdf, November 2, 2015). The standard body mass values for age groups from 1-3 years

156 through adult females and males was based on values used by the U.S. National Academy of

157 Sciences [30]. The specific age-mass groups used were child 1-3 years (13 kg), child 4-8 years

158 (22 kg), children 9-13 years (40 kg), adolescent female 14-18 years (57 kg). adolescent male 14-

15918 years $(64 \mathrm{~kg})$, adult female $19+$ years $(61 \mathrm{~kg})$, and adult male $19+$ years $(76 \mathrm{~kg})$. To provide a

160 frame of reference for the interpreting the calculated dietary intake rates for $\mathrm{Zn}$ and $\mathrm{Cu}$ were

161 compared to oral reference doses (oral RfD) for the elements. The oral RfD represents the daily

162 exposure to a potential hazard that is likely to be without risk of deleterious effects over a

163 lifetime [31]. The oral RfD values for $\mathrm{Zn}\left(300 \mu \mathrm{g} \mathrm{kg}^{-1} \mathrm{~d}^{-1}\right)$ and $\mathrm{Cu}\left(40 \mu \mathrm{g} \mathrm{kg}^{-1} \mathrm{~d}^{-1}\right)$ were obtained

164 from the U.S. EPA Health Effects Assessment Summary Tables (HEAST)[32]. There is no

165 established oral RfD for Ce. To provide surrogate parameters for comparison, the oral RfD

166 values for nine other rare earth elements (Eu, La, Ly, Nd, Pr, Sc, Sm, U, Y) were obtained.[33]

167 As these values range from 0.9 to $500 \mu \mathrm{g} \mathrm{kg}^{-1} \mathrm{~d}^{-1}$, the mean $\left(171.9 \mu \mathrm{g} \mathrm{kg}^{-1} \mathrm{~d}^{-1}\right)$ and median $(5 \mu \mathrm{g}$

$168 \mathrm{~kg}^{-1} \mathrm{~d}^{-1}$ ) values were calculated and used here as general indicators of the oral RfD for Ce. 


\subsection{Data analysis}

The soil to tuber transfer factor (TF) was calculated as the ratio of the concentration of

172 metal in the unpeeled or peeled tuber divided by the metal concentration (on a dry weight basis)

173 in the soil. The percent of $\mathrm{Zn}, \mathrm{Cu}$, or Ce element in either the tuber peel or tuber flesh was

174 calculated by dividing the mass of the element in that tissue (peel or flesh) by the total mass of

175 that metal in the entire unpeeled tuber. Each tuber yield parameter and the tuber metal

176 concentration was analyzed using a two-way ANOVA with concentration and chemical form

177 (ENP or ionic) as the main effects. For the transfer factor, a three-way ANOVA was used with

178 concentration, chemical form, and peeling (i.e., unpeeled or peeled tubers) as the main effects for

179 a given element. If interactions between main effects were observed, the data were reanalyzed

180 treating interacting factors as independent treatments. Analyses were carried out in SPSS (ver.

$18122)$ [34] with Duncan's test used for a post hoc comparison of the means.

182

\section{$183 \quad 3.0$ Results}

\section{$184 \quad 3.1$ Tuber formation and biomass}

There were no apparent signs of stress or toxicity in the aboveground tissues for any of

186 the plants throughout the growth period. By the time of harvest, most of the leaves had naturally

187 abscised from the stems, precluding an accurate measurement of aboveground biomass. There

188 were some pots in all treatments, including the control that did not produce commercial grade

189 tubers. These pots produced sweet potato culls (soft, poorly shaped, cracked, or undersized

190 tubers) that are not marketable yield or retained for human consumption. These pots were

191 excluded from further analysis. As a whole, the control pots showed $80 \%$ success in tuber 
192 formation (i.e., 4 out of 5 pots formed commercial grade tubers, Table S1). Results from the 193 metal nanoparticle and ionic treatments were similar to the control with the exception of those

194 receiving the highest ionic $\mathrm{Zn}$ concentration (40\%, 2 out of 5 pots formed tubers). Yield

195 parameters for pots that successfully formed tubers are summarized in Table 1. None of the

196 parameters showed a significant difference between the ENP and ionic forms. There were no

197 significant differences as a function of concentration for most parameters. Some differences

198 observed for tuber biomass or number of tubers occurred for the highest treatment concentration

199 relative to the other concentrations. There was a significant effect of $\mathrm{Cu}$ concentration on tuber

200 diameter and length and for tuber diameter in response to Ce.

\subsection{Metal concentration in the tubers}

There was a two-way interaction between the tissue type and concentration for $\mathrm{Zn}$ and $\mathrm{Ce}$

204 concentration in the tubers while for $\mathrm{Cu}$ there was three-way interaction between tissue type, 205 concentration, and form (Figure 1). A general concentration-dependent increase was observed

206 for metal concentrations of each element with peels showing the highest concentration. The 207 magnitude of the difference in peel concentration relative to that of unpeeled or peeled tubers 208 was greatest for $\mathrm{Ce}$ and least for $\mathrm{Zn}$. The concentration of $\mathrm{Cu}$ and $\mathrm{Ce}$ in unpeeled tubers was 209 typically significantly less as compared to unpeeled tubers.

\subsection{Contribution of the tuber peel to metal retention}

212 The contribution of the tuber peel to the retention of $\mathrm{Zn}, \mathrm{Cu}$ or $\mathrm{Ce}$ was examined in two 213 ways - using the soil to tuber transfer factor (ratio of tuber concentration to soil concentration)

214 and by expressing the metal accumulation results on a mass basis in terms of the total percent of 
215 tissue metal present in the tuber peel relative to the entire tuber. The transfer factor (TF) values

216 were determined for unpeeled or peeled tubers with ENP or ionic treated sweet potatoes (Figure

217 2). There was no significant difference in TF for $\mathrm{Zn}$ between metal form (ENP or ionic) and for

218 unpeeled and peeled tubers. The TF for the $100 \mathrm{mg} \mathrm{Zn} \mathrm{kg} \mathrm{DW}^{-1}$ concentration was significantly

219 higher than the other two treatments, although the magnitude of the difference was no more than

220 two- to three-fold. There was a significant two-way interaction between concentration and

221 peeling for $\mathrm{Cu}$. For $\mathrm{Ce}$ there were no significant differences as a function of form or

222 concentration. There was however a highly significant difference between unpeeled and peeled

223 tubers. The metal accumulation and the TF values for $\mathrm{Zn}$ indicated that the peels represented a

224 consistent but small percentage of the total metal accumulated by the tuber (data not shown).

225 The tuber peel accounted for 30 to $70 \%$ of the total metal associated with $\mathrm{Cu}$-treated plants

226 (Figure 3). The percentage values for Ce were higher, ranging from $>75 \%$ to $>95 \%$ of the total

227 metal.

228

3.4 Projected dietary intake of $\mathrm{Zn}, \mathrm{Cu}$, or Ce from consumption of treated tubers

230 Dietary intake modeling was performed for all three elements and using unpeeled or

231 peeled tubers from the two highest ENP or ionic exposures (Figure 4). There was little

232 difference in projected dietary intake of $\mathrm{Zn}$ from unpeeled or peeled tubers from ENP-treated

233 plants and none of the values for any age-mass class approached the oral RfD for Zn. For tubers

234 from the ionic Zn-treated plants, the projected dietary exposures were similar to the values for

235 the ENP form for the $500 \mathrm{mg} \mathrm{Zn} \mathrm{kg} \mathrm{DW}^{-1}$ treatment but higher for the $1,000 \mathrm{mg} \mathrm{Zn} \mathrm{kg} \mathrm{DW}$

236 exposure level. The oral RfD for Zn was exceeded only in one instance, namely for the 1-3 year

237 old child age-mass class and the $1,000 \mathrm{mg} \mathrm{Zn} \mathrm{kg}^{-1}$ ionic treatment. The projected dietary 
exposure for $\mathrm{Cu}$ exceeded the oral RfD only for the highest ENP concentration, unpeeled tubers, and the smallest of the age-mass classes. The projected dietary exposures from consumption of unpeeled, ENP-treated tubers at $500 \mathrm{mg} \mathrm{Cu} \mathrm{kg} \mathrm{DW}^{-1}$ were similar to those for the $1,000 \mathrm{mg} \mathrm{Cu}$ $\mathrm{kg} \mathrm{DW}^{-1}$ ionic exposure, although the values were higher than the corresponding projected intakes for unpeeled tubers from the corresponding ionic $\mathrm{Cu}$ treated plants. The projected dietary intake for peeled tubers at $500 \mathrm{mg} \mathrm{Cu} \mathrm{kg} \mathrm{DW}^{-1}$ were similar to those for the 1,000 $\mathrm{mg} \mathrm{Cu}$ $\mathrm{kg} \mathrm{DW}^{-1}$ treatment. The same general trends observed for unpeeled tubers from $\mathrm{Cu}$-treated plants were also observed for unpeeled tubers from Ce-treated plants when the tubers were compared to the median oral RfD value of $5 \mu \mathrm{g} \mathrm{kg}^{-1} \mathrm{~d}^{-1}$ for nine rare earth elements (REEs). However if the data are compared to the mean oral RfD value of $171.9 \mu \mathrm{g} \mathrm{kg}^{-1} \mathrm{~d}^{-1}$ for these same nine elements, all projected dietary exposures fell more than 10 -fold below this value. The projected dietary exposures for peeled tubers were much lower than that for the unpeeled tubers (data not shown), consistent with the results above showing that the majority of Ce from each treatment was associated with the peel tissue. Neither oral RfD values would be exceeded for any of the dietary projections made for peeled, ENP- or ionic-treated sweet potato tubers.

\subsection{Discussion}

The discharge of engineered nanoparticles into the environment, both intentionally and unintentionally, is anticipated based on their growing use. As metal oxide ENPs are expected to be released from consumer products into wastewaters and retained in the sewage sludge, land application of biosolids represents a potential source of ENPs in agricultural systems [35-37]. Additional potential sources of ENPs in agricultural soils include irrigation water, aerial deposition, or the application of nano-enabled products [38-40]. This potential for nanoparticle 
261 release has created the need for studies examining the impact on the growth and yield of

262 agricultural crops as well as the possible accumulation of ENP-derived metals in the edible plant 263 tissues.

264 Studies examining the impact of ENPs on crops have reported contrasting effects of ENP 265 treatment on biomass or yield. Individual studies with soybean (Glycine max) and $\mathrm{ZnO}$, wheat

266 (Triticum aestivum) and $\mathrm{CeO}_{2}$, or carrot and $\mathrm{CuO}$ reported no negative impacts of ENP treatment 267 on biomass or yield $[4,19,25]$. In contrast, some species have displayed negative yield effects 268 in response to ENPs. Examples include a reduction in pod biomass for soybean exposed to $\mathrm{CeO}_{2}$ 269 [19], reduction in the number of developed cobs for corn (Zea mays) in the presence of $\mathrm{ZnO}$ 270 [20], and a reduction in fruit yield for cucumber (Cucumis sativus) following exposure to $\mathrm{CeO}_{2}$ 271 [21]. Not surprisingly, all these studies have reported a significant increase in the concentration 272 of the metal in vegetative tissues upon ENP exposure and in some cases, also in the edible 273 tissues. In the study here there were no specific benefits to sweet potato yield from any of the 274 treatments aside from modest effects on tuber diameter or length observed in some instances. Several characteristics of soil systems, such as the $\mathrm{pH}$, mineralogy (particularly the clay 276 content), organic matter content, and ionic strength, are known to influence the solubility, 277 bioavailability, and toxicity of ENPs to biota [37, 41]. Organic matter has a notable effect on the 278 solubility, dissolution, and uptake of ENPs [37, 42-46]. Organic matter can also affect the 279 solubility of heavy metals, particularly $\mathrm{Cu}[47,48]$. Most of the life cycle studies cited above 280 [19-21] used predominantly sandy soils (e.g., 66-84\% sand) with low organic matter content $281(<5 \%)$. The Fafard potting mix used in this experiment was $50 \%$ sphagnum moss by mass and 282 also included composted pine bark in the formulation. This material provided an organic 283 fraction that likely interacted with both the added nanomaterials and ionic metals, effectively 
284 mitigating their toxicity. Analyses were not conducted to assess the solubility or speciation of

285 the metals in the ENP- and ionic-amended substrates, but the tuber metal concentrations

286 illustrated a dose-dependent relationship, indicative of the relative plant bioavailability of each

287 metal at each concentration. Biological transport mechanisms for these three elements differ in

288 plants and this likely contributes to these trends. However, if one considers the concentration for

289 unpeeled tubers or the tuber peels, this could reflect adsorption of the elements as opposed to

290 biological transport and could therefore be used to make inferences about the solubility and

291 bioavailability of these three metals. One important limitation to this assumption is that there

292 may have been residual soil particles adhering to the tuber peel that were not removed after

293 harvest. As the concentration of the metal treatments increased in the soil, residual soil particles

294 may have inflated the peel concentrations. This contention would need to be evaluated using

295 tubers that had been more thoroughly cleaned to minimize or preclude the effects of soil

296 retention. Nevertheless, overall for this substrate and possibly for other high organic content

297 substrates, adverse effects for sweet potato yield would likely occur only at concentrations that

298 exceed 1,000 mg Zn kg DW $\mathrm{mb}^{-1}$ and perhaps higher for $\mathrm{Cu}$ or $\mathrm{Ce}$. These concentrations are most

299 likely well above those that would be encountered under current exposure regimes (excluding a

300 spill scenario), which may argue against significant concerns of adverse effects on this crop from

301 these ENPs.

302

An unexpected result observed throughout this study was that there were few instances of

303 significant differences in effect or accumulation as a function of chemical form (ENP or ionic).

304 A meta-analysis of ecotoxicity studies for $n \mathrm{ZnO}$ and $n \mathrm{CuO}$ found that the vast majority of

305 studies reported that ionic $\mathrm{Zn}^{2+}$ or $\mathrm{Cu}^{2+}$ was more toxic than $n \mathrm{ZnO}$ or $n \mathrm{CuO}$ when the ENP and

306 ionic forms are presented at equivalent concentrations [49]. Several nanotoxicology studies with 
plants similarly found that the ENP form was either less toxic or no more toxic than the ionic

308 form $[25,50-54]$. Both $n \mathrm{ZnO}$ and $n \mathrm{CuO}$ can undergo rapid dissolution to release component

309 ions $[55,56]$, with the rate of $n \mathrm{ZnO}$ dissolution generally more rapid than that of $n \mathrm{CuO}$ [57].

310 The stability of $n \mathrm{CeO}_{2}$ is higher $[13,58]$ but dissolution does occur with the rate dependent on

311 the chemical conditions in the media $[46,59]$ and biological effects mediated by plant roots [59].

312 Over the $130 \mathrm{~d}$ treatment period there was considerable time for these nanomaterials to undergo

313 dissolution. The similarity in the results throughout this study suggest that the bioavailable

314 fraction in this substrate did not differ substantially between the two chemical forms of these

315 three metals. Had the speciation of the metals been examined in the substrate during or after the

316 treatment period, it may have been possible to confirm the dissolution of the nanomaterials and

317 the plant bioavailability of $\mathrm{Zn}, \mathrm{Cu}$, or $\mathrm{Ce}$. Techniques such as $\mathrm{UXRF}$ and XANES have been

318 used in some studies to demonstrate the speciation and chemical form of the target metals [60,

319 61]. The results underscore the importance of soil characteristics and processes in assessing the

320 impact and accumulation of nanomaterials in plants.

Anatomically speaking, the "peel" of a sweet potato tuber is composed largely of

322 periderm, a tissue composed of an outer phellem (or cork layer), a layer of dividing cork

323 cambium cells (phellogen), and a layer of parenchymal cells (phelloderm) inside the phellogen.

324 The phellem layer replaces the epidermis as the outer protective cell layer and plays a key role in 325 the resistance to pests [62]. Phellem cells are dead at maturity and have thin cell walls that are 326 partially lignified [63]. Other root and tuberous vegetables have a similar structure to their 327 belowground storage organ. This layer of dead cells in the vegetable surface has in studies with 328 radish (Raphanus sativus) and carrot been shown to restrict the penetration of ENPs more so than 329 ionic forms of metals $[25,53]$. Such results suggest that for these vegetables, the peridem (i.e., 
the peel) acts as a screen to restrict the inward radial transfer of ENPs. Presumably then, if there

331 is no difference for the roots or tubers of a plant species in accumulation between the ENP and

332 ionic forms, then there are at least two possibilities. One is that the species may have less

333 selectivity than that for carrot and radish, therefore allowing the ENP to penetrate as readily as

334 the ion. In contrast, perhaps the more plausible explanation is that tissues were in contact with

335 ionic $\mathrm{Zn}, \mathrm{Cu}$, or $\mathrm{Ce}$ in both the ENP and ionic treatments. The latter possibility could be

336 investigated if soil-based studies of ENP uptake by plants provided data characterizing the

337 dissolution, speciation, and or bioavailability of the ENPs or their metals in the soils.

338 The goal of the dietary intake projections was to relate the accumulation of $\mathrm{Zn}, \mathrm{Cu}$, or $\mathrm{Ce}$

339 in unpeeled and peeled tuber from the two forms (ENP or ionic) to a potential impact on human

340 consumers. The oral RfD for chronic dietary intake was selected as a parameter to provide

341 context for those dietary intake values. This is difficult for Ce since there is no oral RfD for this

342 element. The lack of a value was compensated for through the use of a median and a mean value

343 calculated from the oral RfD values for nine other REEs. These two values for the REEs varied

344 by more than 20 -fold and the more conservative of the two values was used to evaluate the

345 dietary intake of Ce. There was little difference in the dietary intake trends with the exception of

346 the Zn. Overall there was little indication that there would be dietary exposure in excess of the

347 oral RfD except if the tubers were consumed unpeeled by small children. It is doubtful that

348 children of that age would consume a full serving so the dietary intake would likely be

349 substantially lower. In addition, dietary intake in excess of the oral RfD was projected primarily

350 for plants grown at the highest treatment concentration $\left(1,000 \mathrm{mg} \mathrm{kg} \mathrm{DW}^{-1}\right)$. Whether this

351 concentration of ENP would be reached under environmentally realistic exposure scenarios is

352 unknown but is either unlikely or would require considerable time (absent a spill situation or 
other unintended massive release) to reach through repeated introduction of ENPs. As illustrated here, projecting dietary intake based on the ionic metal produced very similar results to those for the ENP form, indicating that the potential risks posed by ENPs in soil grown plants are likely no worse than those for the comparable ionic treatment. This assumes however that effects of metal oxide ENPs even if intact in plant foods on consumers are no different than those that might be caused by the same amount of the ionic metal. Specific nano-effects that manifest after consumption still need to be investigated to provide a more complete picture of the potential impacts of ENPs in plant foods. The value of peeling the tubers in terms of dietary intake was clearly illustrated by the data, even when the highly conservative median oral RfD for the REEs was employed for Ce. The same interpretations were made for dietary intake of carrot exposed to $n \mathrm{ZnO}, n \mathrm{CuO}$, or $n \mathrm{CeO}_{2}$ or the ionic counterpart [25]. Peeling root and tuberous vegetables therefore represents a simple step to ameliorate potential exposure to ENPs or ionic metals. One other means of mitigating potential dietary intake would be to more thoroughly clean the surface of the tubers. The study here did not use an aggressive strategy to clean the tuber surface. A more vigorous abrasion of the surface, perhaps with the addition of surfactants, could remove a larger fraction of metals associated with the peels, creating a commensurate decrease in the potential dietary intake.

\subsection{Conclusions}

The results from this sweet potato life cycle microcosm study with $n \mathrm{ZnO}, n \mathrm{CuO}$, and $n \mathrm{CeO}_{2}$ demonstrated that in this soil system, adverse effects on yield (if present) were only observed at the higher exposure concentrations used and were independent of the chemical form of the metal. In comparing the tuber concentration and transfer factor data between the three 
metals, the results imply that $\mathrm{Zn}$ was more bioavailable than $\mathrm{Cu}$, which was in turn more bioavailable than $\mathrm{Ce}$. The lack of a difference in sweet potato tuber yield or metal concentration between the chemical forms could suggest that the plants were not actually exposed to the ENP but were instead exposed predominantly to the ionic forms. This is further supported by the observation that the peels of sweet potato had higher concentrations of metals than the inner tuber flesh, but there was no consistent evidence of differential accumulation between the ENPand ionic-treated plants. With respect to the associated of metals with the peels, one trend that was clear from the results is that regardless of chemical form (ENP versus ionic), sweet potato peel screened considerably more $\mathrm{Ce}$ than $\mathrm{Zn}$ or $\mathrm{Cu}$. Overall, adverse outcomes in terms of reductions in sweet potato yield, metal accumulation, and dietary intake occurred regardless of the chemical form of the metal added to the substrate but were predominantly associated with exposure concentrations unlikely to occur in the environment. These results imply that under such conditions, ENPs pose no greater risk to agricultural productivity or food safety than do the ionic metals. The results also highlight several research areas for future study with regard to nanomaterials and food safety. More realistic estimates of the likely concentrations of ENPs that would occur in the environment are needed. Investigation of the subsequent accumulation of metal oxide ENPs by agricultural crops needs to be linked to studies of ENP chemical fate and speciation in soil, as well as in biota. Several recent studies have successfully used uXRF and/or XANES to characterize the in vivo speciation of metals in plant tissues originating from metallic oxide ENPs [20, 21, 58, 64-66]. Determining the in vivo speciation and conformation of the metals is necessary then to assess internal distribution and potential impact to plants. Such information is paramount to the subsequent assessment of their biological effects and the mechanism of accumulation in food crops. Investigation of the impact of consumption on 
399 animal consumers have largely been limited to projected intake, as was done in this study [19,

400 67]. There is a pressing need for studies that provide information on the actual form and

401 concentration of dietary exposure that results from the consumption of plant foods grown in the

402 presence of metallic oxide ENPs. With such data, a more conclusive determination of the risks

403 of ENPs to food safety and human health would be possible.

404

$405 \quad 6.0$ Acknowledgments

406 Funding for this research was provided by a grant from USDA-NIFA to SDE (\#2012-67005-

407 19585). JCW acknowledges USDA-NIFA (\#2011-67006-30181). The authors would like to

408 thank Shayla Gunn, Anthony Sabella, Cassandra Turner, Taylor Ingram, Kristina Jordan, and

409 Laxmi Sagwan for this assistance during the growth and harvesting of the sweet potato plants. 
412 [1] A. Nel, T. Xia, L. Madler, N. Li, Toxic potential of materials at the nanolevel, Sci. Total Environ., 311 413 (2006) 622-627.

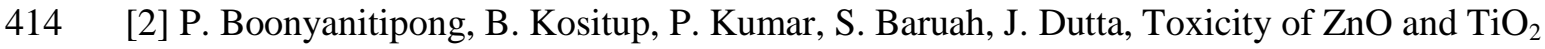

415 nanoparticles on germinating rice seed Oryza sativa L., International Journal of Bioscience, Biochemistry, 416 and Bioinformatics, 1 (2011) 282-285.

417 [3] W.-M. Lee, Y.-J. An, H. Yoon, H.-S. Kweon, Toxicity and bioavailability of copper nanoparticles to 418 the terrestrial plants mung bean (Phaseolus radiatus) and wheat (Triticum aestivum): Plant agar test for 419 water-insoluble nanoparticles, Environ. Toxicol. Chem., 27 (2008) 1915-1921.

420 [4] W. Du, J.L. Gardea-Torresdey, R. Ji, Y. Yin, J. Zhu, J.R. Peralta-Videa, H. Guo, Physiological and 421 biochemical changes imposed by $\mathrm{CeO}_{2}$ nanoparticles on wheat: A life cycle field study, Environ. Sci. 422 Technol., 49 (2015) 11884-11893.

423 [5] C.O. Dimkpa, J.E. McLean, D.W. Britt, A.J. Anderson, Bioactivity and biomodification of Ag, ZnO, 424 and $\mathrm{CuO}$ nanoparticles with relevance to plant performance in agriculture, Indust. Biotechnol., 8 (2012) $425 \quad 344-357$.

426 [6] J.L. Gardea-Torresdey, C.M. Rico, J.C. White, Trophic transfer, transformation, and impact of 427 engineered nanomaterials in terrestrial environments, Environ. Sci. Technol., 48 (2014) 2526-2540.

428 [7] P. Miralles, T.L. Church, A.T. Harris, Toxicity, uptake, and translocation of engineered nanomaterials 429 in vascular plants, Environ. Sci. Technol., 46 (2012) 9224-9239.

430 [8] C. Ma, J.C. White, O.P. Dhankher, B. Xing, Metal-based nanotoxicity and detoxification pathways in 431 higher plants, Environ. Sci. Technol., 49 (2015) 7109-7122. 
432 [9] J.D. Judy, P.M. Bertsch, Bioavailability, toxicity, and fate of manufactured nanomaterials in terrestrial 433 ecosystems, in: L.S. Donald (Ed.) Advances in Agronomy, Academic Press, 2014, pp. 1-64.

434 [10] M. Ghosh, M. Bandyopadhyay, A. Mukherjee, Genotoxicity of titanium dioxide (TiO2)

435 nanoparticles at two trophic levels: Plant and human lymphocytes, Chemosphere, 81 (2010) 1253-1262.

436 [11] M. Kumari, S.S. Khan, S. Pakrashi, A. Mukherjee, N. Chandrasekaran, Cytogenetic and genotoxic 437 effects of zinc oxide nanoparticles on root cells of Allium cepa, J. Hazard. Mater., 190 (2011) 613-621.

438 [12] M. Ruffini Castiglione, L. Giorgetti, C. Geri, R. Cremonini, The effects of nano-TiO2 on seed 439 germination, development and mitosis of root tip cells of Vicia narbonensis L. and Zea mays L, J. Nano. $440 \quad$ Res., 13 (2011) 2443-2449.

441 [13] M.L. López-Moreno, G. de la Rosa, J.Á. Hernández-Viezcas, H. Castillo-Michel, C.E. Botez, J.R.

442 Peralta-Videa, J.L. Gardea-Torresdey, Evidence of the differential biotransformation and genotoxicity of $443 \mathrm{ZnO}$ and $\mathrm{CeO}_{2}$ nanoparticles on soybean (Glycine max) plants, Environ. Sci. Technol., 44 (2010) 73154447320.

445 [14] S. Majumdar, I.C. Almeida, E.A. Arigi, H. Choi, N.C. VerBerkmoes, J. Trujillo-Reyes, J.P. Flores446 Margez, J.C. White, J.R. Peralta-Videa, J.L. Gardea-Torresdey, Environmental effects of nanoceria on 447 seed production of common bean (Phaseolus vulgaris): A proteomic analysis, Environ. Sci. Technol., 49 $448 \quad$ (2015) 13283-13293.

449 [15] C. Vannini, G. Domingo, E. Onelli, B. Prinsi, M. Marsoni, L. Espen, M. Bracale, Morphological and 450 proteomic responses of Eruca sativa exposed to silver nanoparticles or silver nitrate, PloS one, 8 (2013) $451 \quad \mathrm{e} 68752$. 
[16] F. Mirzajani, H. Askari, S. Hamzelou, Y. Schober, A. Römpp, A. Ghassempour, B. Spengler, Proteomics study of silver nanoparticles toxicity on Oryza sativa L, Ecotoxicology and environmental 454 safety, 108 (2014) 335-339.

[17] P. Landa, R. Vankova, J. Andrlova, J. Hodek, P. Marsik, H. Storchova, J.C. White, T. Vanek, Nanoparticle-specific changes in Arabidopsis thaliana gene expression after exposure to $\mathrm{ZnO}, \mathrm{TiO}_{2}$, and 457 fullerene soot, J. Hazard. Mater., 241-242 (2012) 55-62.

[18] C. Ma, S. Chhikara, B. Xing, C. Musante, J.C. White, O.P. Dhankher, Physiological and molecular 459 response of Arabidopsis thaliana (L.) to nanoparticle cerium and indium oxide exposure, ACS Sustain. 460 Chem. Engr., 1 (2013) 768-778.

[19] J.H. Priester, Y. Ge, R.E. Mielke, A.M. Horst, S.C. Moritz, K. Espinosa, J. Gelb, S.L. Walker, R.M. 462 Nisbet, Y.-J. An, J.P. Schimel, R.G. Palmer, J.A. Hernandez-Viezcas, L. Zhao, J.L. Gardea-Torresdey, 463 P.A. Holden, Soybean susceptibility to manufactured nanomaterials with evidence for food quality and 464 soil fertility interruption, P. Natl. Acad. Sci. USA, 109 (2012) E2451-E2456.

[20] L. Zhao, Y. Sun, J.A. Hernandez-Viezcas, J. Hong, S. Majumdar, G. Niu, M. Duarte-Gardea, J.R.

466 Peralta-Videa, J.L. Gardea-Torresdey, Monitoring the environmental effects of $\mathrm{CeO}_{2}$ and $\mathrm{ZnO}$ nanoparticles through the life cycle of corn (Zea mays) plants and in situ $\mu$-XRF mapping of nutrients in 468 [21] L. Zhao, Y. Sun, J.A. Hernandez-Viezcas, A.D. Servin, J. Hong, G. Niu, J.R. Peralta-Videa, M. Duarte-Gardea, J.L. Gardea-Torresdey, Influence of $\mathrm{CeO}_{2}$ and $\mathrm{ZnO}$ nanoparticles on cucumber 471 physiological markers and bioaccumulation of Ce and Zn: A life cycle study, J. Agric. Food Chem,, 61 472 (2013) 11945-11951. 

nanomaterials, J. Nano. Res., 15 (2013) 1692.

[24] G. Antonious, S. Dennis, J. Unrine, J. Syder, Heavy metals uptake in plant parts of sweet potato grown in soil fertilized with municipal sewage sludge, International Journal of Geology, 5 (2011) 14-20.

[25] S.D. Ebbs, S. Bradfield, P. Kumar, C. Musante, J.C. White, X. Ma, Accumulation of zinc, copper, or cerium in carrot (Daucus carota) exposed to metal oxide nanoparticles and metal ions, Environ. Sci.:

$481 \quad$ Nano, 3 (2016) 114-126.

[26] S.D. Ebbs, S.J. Bradfield, P. Kumar, J.C. White, X. Ma, Projected dietary intake of zinc, copper, and 483 cerium from consumption of carrot (Daucus carota) exposed to metal oxide nanoparticles or metal ions 484 Frontiers in Plant Science, (2016) In press. [27] USEPA, Method 3050b: Acid Digestion of Sediments, Sludges, and Soils in: Test Methods for Evaluating Solid Waste Physical/Chemical Methods, SW-846 Environmental Protection Agency, Office of Solid Waste, Washington, DC, 1996, pp. 12 pp.

[28] S.D. Ebbs, J. Talbott, R. Sankaran, Cultivation of garden vegetables in Peoria pool sediments from 489 the Illinois River: A case study in trace element accumulation and dietary exposures, Environ. Int., 32 $490 \quad$ (2006) 766-774.

[29] S. Ebbs, S. Hatfield, V. Nagarajan, M. Blaylock, A comparison of the dietary arsenic exposures from 492 ingestion of contaminated soil and hyperaccumulating Pteris ferns used in a residential phytoremediation 493 project, Int. J. Phytoremediat., 12 (2010) 121-132.

494 [30] National Academy of Sciences, Dietary Reference Intakes for Vitamin A, Vitamin K, Arsenic, 495 Boron, Chromium, Copper, Iodine, Iron, Manganese, Molybdenum, Nickel, Silicon, Vanadium, and Zinc, 496 National Academy Press, Washington, D.C., 2001. 
497 [31] Agency for Toxic Substances and Disease Registry (ATSDR), Toxicological profile for copper, U.S. 498 Department of Health and Human Services, Public Health Service, Atlanta, GA, 2004.

499 [32] U.S. EPA, Health Effects Assessment Summary Tables (HEAST), in, U.S. Environmental Protection 500 Agency, Washington, DC, 1997.

501 [33] USEPA, Rare earth elements: A review of production, processing, recycling, and associated 502 environmental issues, in, Office of Research and Development, Cincinnati, OH, 2012.

503 [34] IBM Corp., IBM SPSS Statistics for Windows, Version 19.0., IBM Corp., Armonk, NY 2010.

504 [35] F. Gottschalk, T. Sonderer, R.W. Scholz, B. Nowack, Modeled environmental concentrations of 505 engineered nanomaterials $\left(\mathrm{TiO}_{2}, \mathrm{ZnO}, \mathrm{Ag}, \mathrm{CNT}\right.$, Fullerenes) for different regions, Environ. Sci. Technol., $50643(2009)$ 9216-9222.

507 [36] N.C. Mueller, B. Nowack, Exposure modeling of engineered nanoparticles in the environment, 508 Environ. Sci. Technol., 42 (2008) 4447-4453.

509 [37] P.S. Tourinho, C.A. Van Gestel, S. Lofts, C. Svendsen, A.M. Soares, S. Loureiro, Metal-based 510 nanoparticles in soil: Fate, behavior, and effects on soil invertebrates, Environ. Toxicol. Chem., 31 (2012) $511 \quad 1679-1692$.

512 [38] A. Gogos, K. Knauer, T.D. Bucheli, Nanomaterials in plant protection and fertilization: current state, 513 foreseen applications, and research priorities, J. Agric. Food Chem,, 60 (2012) 9781-9792.

514 [39] S. Mura, G. Seddaiu, F. Bacchini, P.P. Roggero, Advances of nanotechnology in agro-environmental 515 studies, Ital. J. Agron., 8 (2013) e18.

516 [40] S. Suppan, Nanomaterials in Soil: Our Future Food Chain?, in, Institute for Agriculture and Trade 517 Policy, 2013, pp. 17 pp. 
518 [41] B. Pan, B. Xing, Applications and implications of manufactured nanoparticles in soils: a review, Eur.

519 J. Soil Sci., 63 (2012) 437-456.

520 [42] R. Handy, R. Owen, E. Valsami-Jones, The ecotoxicology of nanoparticles and nanomaterials:

521 current status, knowledge gaps, challenges, and future needs, Ecotoxicology, 17 (2008) 315-325.

522 [43] X. Jiang, M. Tong, H. Li, K. Yang, Deposition kinetics of zinc oxide nanoparticles on natural

523 organic matter coated silica surfaces, Journal of Colloid and Interface Science, 350 (2010) 427-434.

524 [44] O.N. Mileyeva-Biebesheimer, A. Zaky, C.L. Gruden, Assessing the impact of titanium dioxide and

525 zinc oxide nanoparticles on bacteria using a fluorescent-based cell membrane integrity assay,

526 Environmental Engineering Science, 27 (2010) 329-335.

527 [45] Y. Zhang, Y. Chen, P. Westerhoff, J. Crittenden, Impact of natural organic matter and divalent 528 cations on the stability of aqueous nanoparticles, Water Research, 43 (2009) 4249-4257.

529 [46] F. Schwabe, R. Schulin, P. Rupper, A. Rotzetter, W. Stark, B. Nowack, Dissolution and

530 transformation of cerium oxide nanoparticles in plant growth media, J. Nano. Res., 16 (2014) 1-11.

531 [47] A. Kabata-Pendias, Trace Elements in Soils and Plants, 4th Ed., CRC Press, Boca Raton, FL, 2011.

532 [48] H. Marschner, Mineral Nutrition of Higher Plants, Academic Press, London, 2003.

533 [49] D.A. Notter, D.M. Mitrano, B. Nowack, Are nanosized or dissolved metals more toxic in the

534 environment? A meta-analysis, Environ. Toxicol. Chem., 33 (2014) 2733-2739.

535 [50] L.R. Pokhrel, B. Dubey, Evaluation of developmental responses of two crop plants exposed to silver 536 and zinc oxide nanoparticles, Sci. Total Environ., 452-453 (2013) 321-332.

537 [51] G. de la Rosa, M.L. López-Moreno, D. de Haro, C.E. Botez, J.R. Peralta-Videa, J.L. Gardea-

538 Torresdey, Effects of $\mathrm{ZnO}$ nanoparticles in alfalfa, tomato, and cucumber at the germination stage: Root 
539 development and X-ray absorption spectroscopy studies, Pure \& Applied Chemistry, 85 (2013) 1261-

5402174.

541 [52] D. Lin, B. Xing, Root uptake and phytotoxicity of ZnO nanoparticles, Environ. Sci. Technol., 42

542 (2008) 5580-5585.

543 [53] W. Zhang, S. Ebbs, C. Musante, J. White, C. Gao, X. Ma, Uptake and accumulation of bulk and 544 nano-sized cerium oxide particles and ionic cerium by radish (Raphanus sativus L.), J Agric. Food Chem, $54563(2015) 382-390$.

546 [54] Q. Wang, S. Ebbs, Y. Chen, X. Ma, Trans-generational impact of cerium oxide nanoparticles on 547 tomato plants Metallomics, 5 (2013) 753-759.

548 [55] N.M. Franklin, N.J. Rogers, S.C. Apte, G.E. Batley, G.E. Gadd, P.S. Casey, Comparative toxicity of 549 nanoparticulate $\mathrm{ZnO}$, bulk $\mathrm{ZnO}$, and $\mathrm{ZnCl}_{2}$ to a freshwater microalga (Pseudokirchneriella subcapitata):

550 The importance of particle solubility, Environ. Sci. Technol., 41 (2007) 8484-8490.

551 [56] C.O. Dimkpa, J.E. McLean, D.E. Latta, E. Manangón, D.W. Britt, W.P. Johnson, M.I. Boyanov, A.J. 552 Anderson, $\mathrm{CuO}$ and $\mathrm{ZnO}$ nanoparticles: Phytotoxicity, metal speciation, and induction of oxidative stress 553 in sand-grown wheat, J. Nano. Res., 14 (2012) 1-15.

554 [57] C.O. Dimkpa, D.E. Latta, J.E. McLean, D.W. Britt, M.I. Boyanov, A.J. Anderson, Fate of CuO and $555 \mathrm{ZnO}$ nano- and microparticles in the plant environment, Environ. Sci. Technol., 47 (2013) 4734-4742.

556 [58] S. Majumdar, J.R. Peralta-Videa, S. Bandyopadhyay, H. Castillo-Michel, J.-A. Hernandez-Viezcas, 557 S. Sahi, J.L. Gardea-Torresdey, Exposure of cerium oxide nanoparticles to kidney bean shows disturbance 558 in the plant defense mechanisms, J. Hazard. Mater., 278 (2014) 279-287. 
560 cerium contributes to uptake of $\mathrm{Ce}$ in the presence of differently sized $\mathrm{CeO}_{2}$-nanoparticles by three crop 561 plants, Metallomics, 7 (2015) 466-477.

562 [60] A. Manceau, K.L. Nagy, M.A. Marcus, M. Lanson, N. Geoffroy, T. Jacquet, T. Kirpichtchikova, 563 Formation of metallic copper nanoparticles at the soil- root interface, Environ. Sci. Technol., 42 (2008) $564 \quad 1766-1772$.

565 [61] J.M. Unrine, O.V. Tsyusko, S.E. Hunyadi, J.D. Judy, P.M. Bertsch, Effects of particle size on 566 chemical speciation and bioavailability of copper to earthworms (Eisenia fetida) exposed to copper 567 nanoparticles, Journal of Environmental Quality, 39 (2010) 1942-1953.

[62] J. Schalk, J. Peterson, A. Jones, P. Dukes, W. Walter Jr, The anatomy of sweet potato periderm and 569 its relationship to wireworm, Diabrotica, Systena resistance, J. Agric. Entomol, 3 (1986) 350-356.

570 [63] E. Artschwager, On the anatomy of the sweet potato root with notes on internal breakdown, Journal 571 of Agricultural Research, 27 (1924).

572 [64] J.D. Judy, J.M. Unrine, P.M. Bertsch, Evidence for biomagnifications of gold nanoparticles within a 573 terrestrial food chain, Environ. Sci. Technol., 45 (2011) 776-781.

574 [65] C. Larue, H. Castillo-Michel, S. Sobanska, N. Trcera, S. Sorieul, L. Cécillon, L. Ouerdane, S. 575 Legros, G. Sarret, Fate of pristine $\mathrm{TiO}_{2}$ nanoparticles and aged paint-containing $\mathrm{TiO}_{2}$ nanoparticles in 576 lettuce crop after foliar exposure, J. Hazard. Mater., 273 (2014) 17-26.

577 [66] A.D. Servin, M.I. Morales, H. Castillo-Michel, J.A. Hernandez-Viezcas, B. Munoz, L. Zhao, J.E. 578 Nunez, J.R. Peralta-Videa, J.L. Gardea-Torresdey, Synchrotron verification of $\mathrm{TiO}_{2}$ accumulation in 579 cucumber fruit: A possible pathway of $\mathrm{TiO}_{2}$ nanoparticle transfer from soil into the food chain, Environ. $580 \quad$ Sci. Technol., 47 (2013) 11592-11598. 
581 [67] A. Weir, P. Westerhoff, L. Fabricius, K. Hristovski, N. von Goetz, Titanium dioxide nanoparticles in 582 food and personal care products, Environ. Sci. Technol., 46 (2012) 2242-2250. 


\section{$584 \quad$ Figure legends}

585 Figure 1. Concentration of $\mathrm{Zn}, \mathrm{Cu}$ or $\mathrm{Ce}$ in unpeeled, peeled tubers, and the peels of sweet 586 potato grown for $130 \mathrm{~d}$ in field microcosms in the presence of three concentrations of each

587 element presented as metal oxide engineered nanoparticles (ENP) or in the ionic form (ion). 588 Data represent the mean and standard error $(n=3-5)$. Within each panel, bars with different 589 letters are significantly different from one another. 1.o.d. = limit of detection.

591 Figure 2. Soil to tuber transfer factors (TF) for unpeeled or peeled sweet potatoes grown for 130 $592 \mathrm{~d}$ in field microcosms in the presence of three concentrations of $\mathrm{Zn}, \mathrm{Cu}$, or Ce presented as either 593 metal oxide nanoparticles or in the ionic form. As there was no significant effect of form within 594 each metal, the data were pooled for the two forms and presented as a function of treatment 595 concentration. Data represent the mean and standard error $(n=3-5)$. Within each panel, bars 596 with different letters are significantly different from one another.

598 Figure 3. Distribution of $\mathrm{Cu}$ or Ce across the peels (outer periderm) and tuber flesh of sweet 599 potato grown for $130 \mathrm{~d}$ in field microcosms in the presence of three concentrations of either 600 element presented as metal oxide engineered nanoparticles (ENP) or in the ionic form (Ion). 601 Data represent the mean and standard error $(n=3-5)$. Within each panel, the letters above the 602 bars denote significant differences in the percentage of metal associated with the peel as a 603 function of form and concentration.

604

605 Figure 4. Dietary intake models for $\mathrm{Zn}, \mathrm{Cu}$, or $\mathrm{Ce}$ based on consumption of a single serving of 606 unpeeled or peeled sweet potato grown for $130 \mathrm{~d}$ in field microcosms in the presence of either 
607500 or $1,000 \mathrm{mg} \mathrm{kg} \mathrm{DW}^{-1}$ of each element presented as metal oxide engineered nanoparticles 608 (ENP, left panels) or in the ionic form (ion, right panels). Intake for each scenario is modeled for 609 seven age-mass classes ranging from child to adult females and males. For $\mathrm{Zn}$ and $\mathrm{Cu}$, the solid 610 line represents the chronic oral RfD value. The solid line for the Ce panels represents the median 611 oral RfD calculated from nine other rare earth elements. Data represent the mean and standard 612 error $(n=3-5)$. 


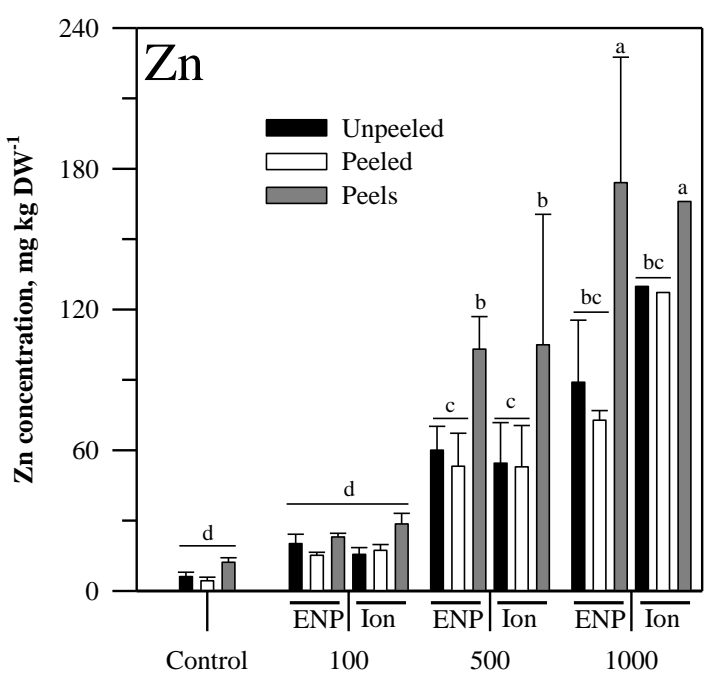

Form and Concentration (mg kg DW' ${ }^{-1}$ )

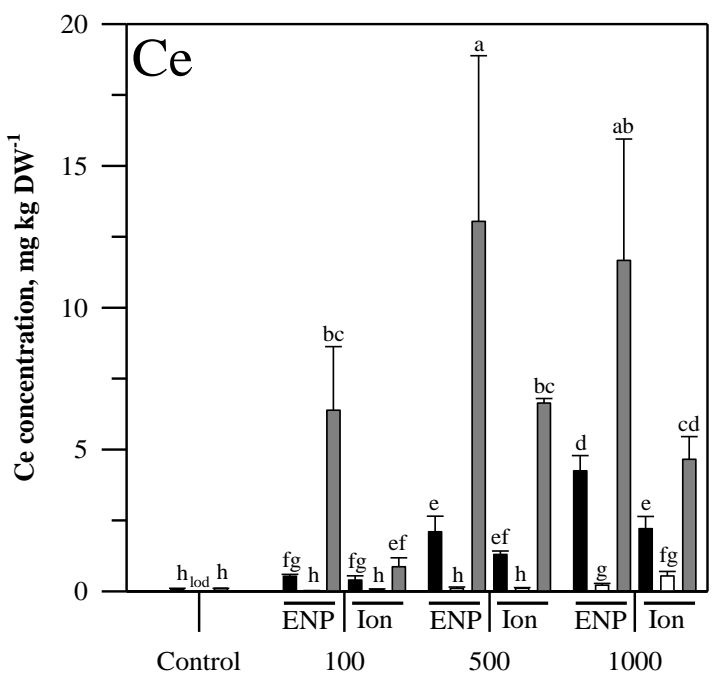

Form and Concentration $\left(\mathrm{mg} \mathrm{kg} \mathrm{DW}^{-1}\right)$

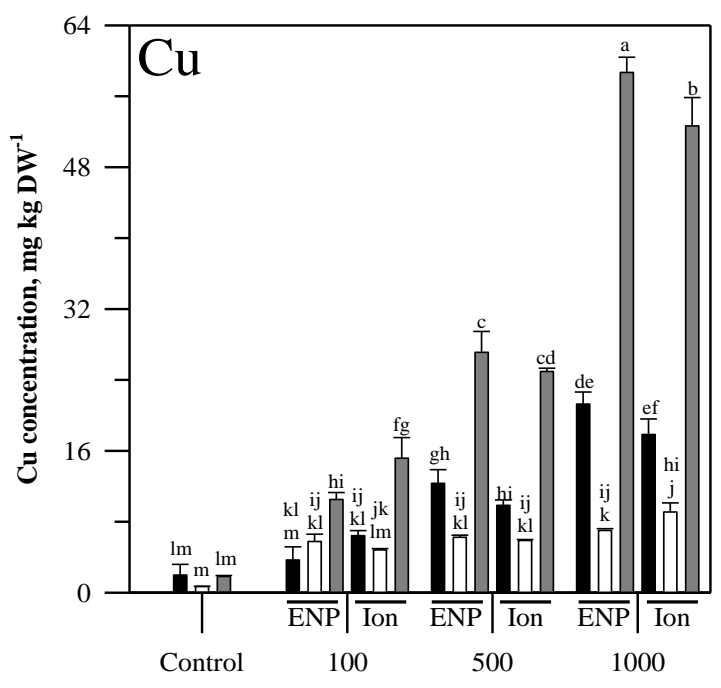

Form and Concentration (mg kg DW'

Figure 1 


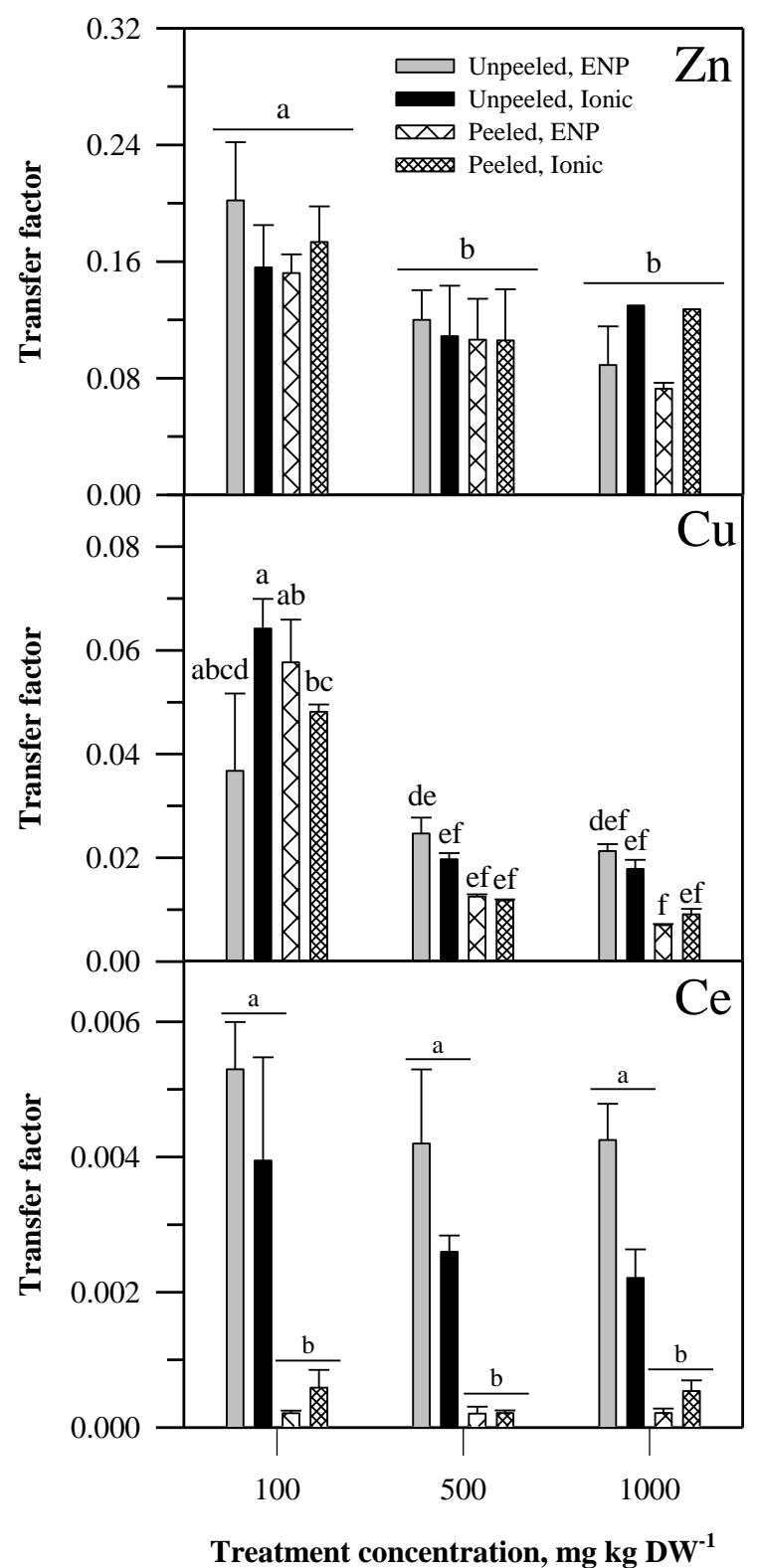

Figure 2 


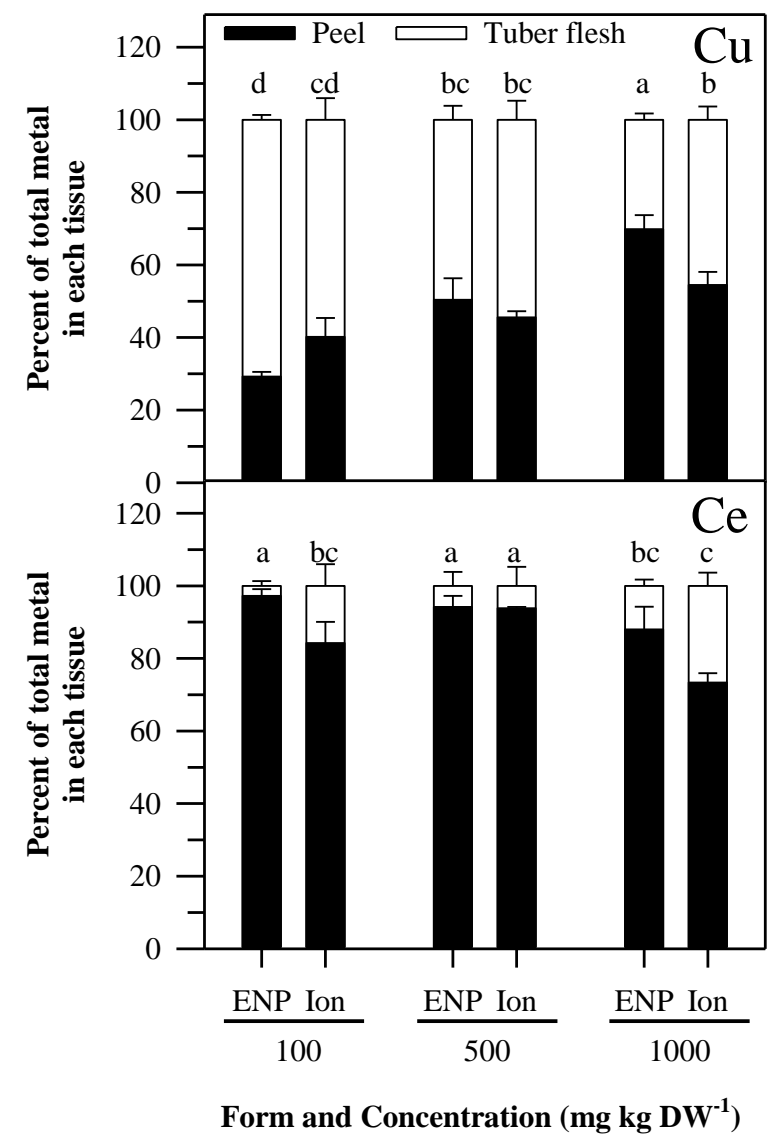

Figure 3 

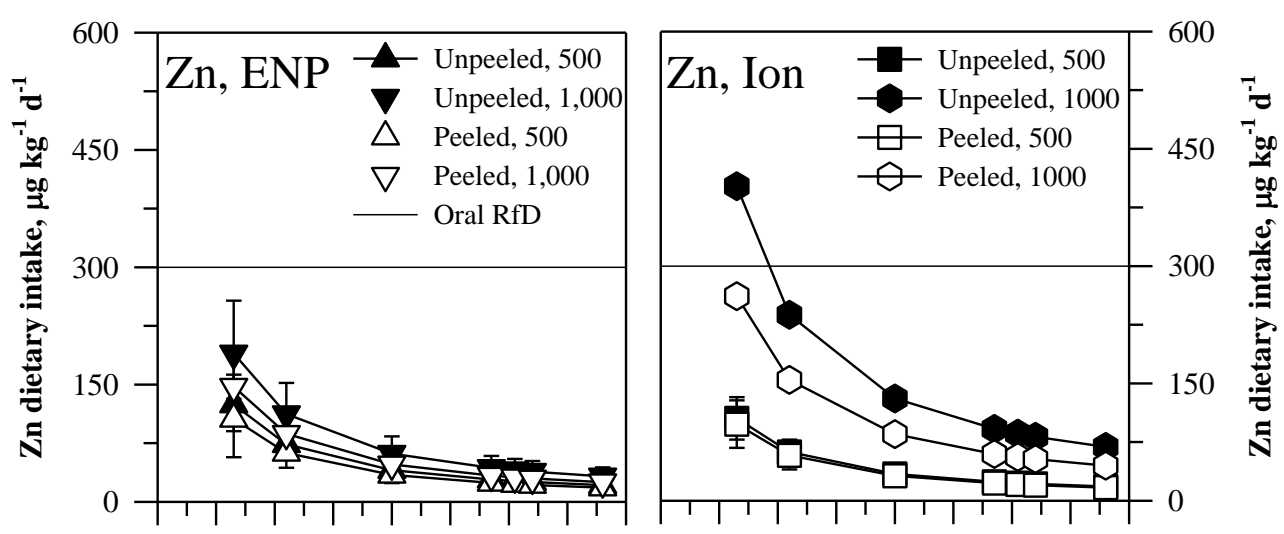

$\begin{array}{lllllllll}0 & 10 & 20 & 30 & 40 & 50 & 60 & 70 & 80\end{array}$

Body mass, kg

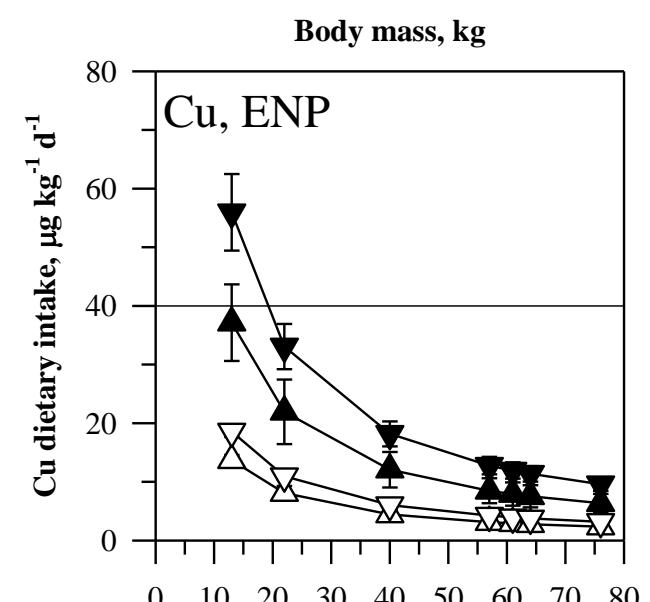

$\begin{array}{llllllll}10 & 20 & 30 & 40 & 50 & 60 & 70 & 80\end{array}$
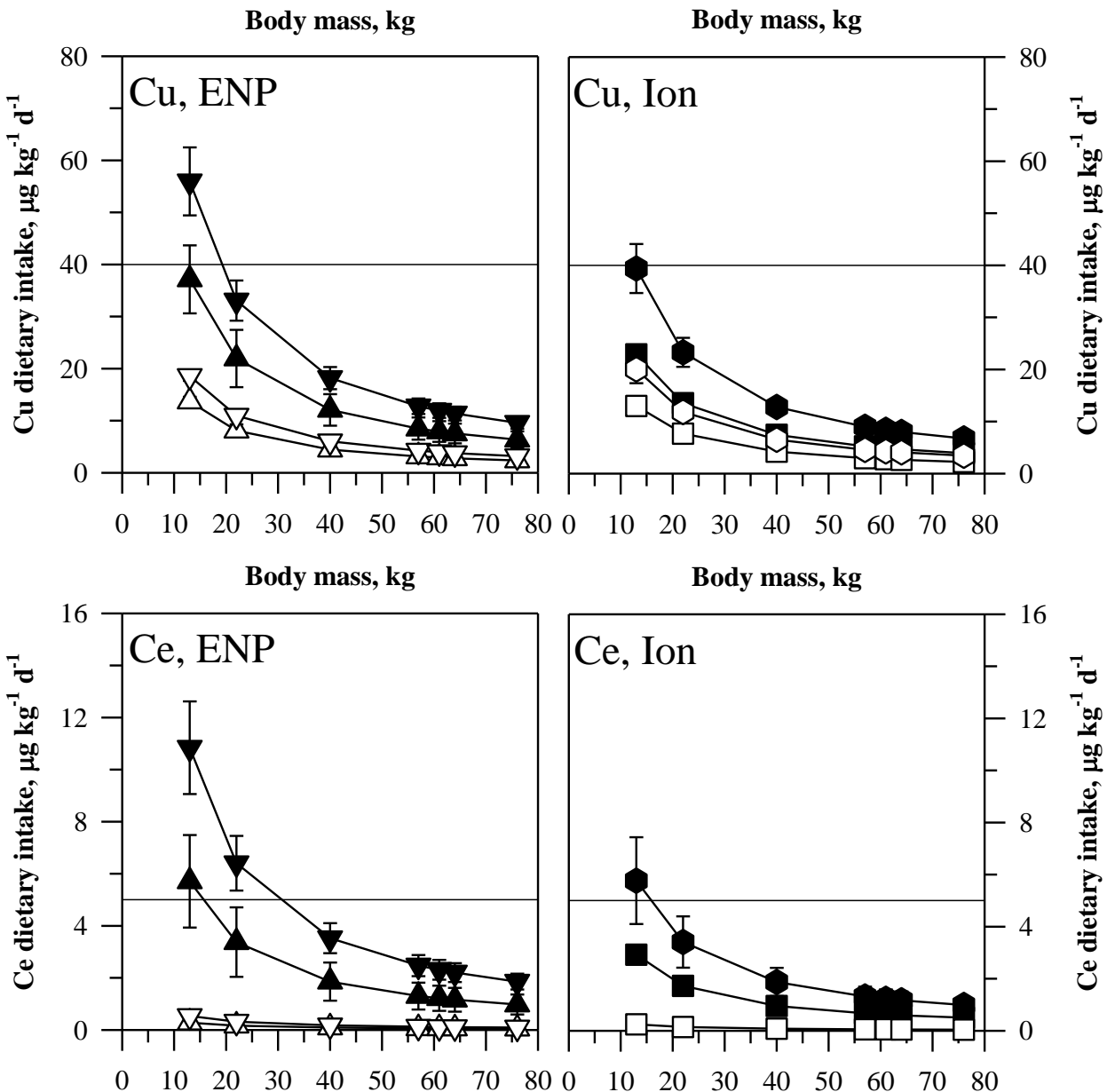

Body mass, kg

Body mass, kg

Figure 4 
Table 1. Yield data for tubers of sweet potato grown in field microcosms containing substrate amended with one of four concentrations of $n \mathrm{ZnO}, n \mathrm{CuO}$, or $n \mathrm{CeO}_{2}$ or the same concentration of $\mathrm{Zn}^{2+}, \mathrm{Cu}^{2+}$, or $\mathrm{Ce}^{4+}$. The results of the two-way ANOVA indicated no effect of form for any metal. There was a significant effect of concentration for some parameters so the results are presented only in terms of treatment concentration. Data illustrate the mean and standard error $(n=3-5)$. Within a metal and an individual parameter, different letters are used to indicate significant differences.

\begin{tabular}{cccccccc}
\cline { 3 - 7 } & \multicolumn{5}{c}{ Yield data for sweet potato tubers } \\
\hline Element & Treatment & Tuber biomass, & $\begin{array}{c}\text { Number of } \\
\text { tubers }\end{array}$ & $\begin{array}{c}\text { Mass per } \\
\text { tuber, g FW }\end{array}$ & $\begin{array}{c}\text { Tuber water } \\
\text { content, \% }\end{array}$ & $\begin{array}{c}\text { Tuber } \\
\text { diameter, cm }\end{array}$ & $\begin{array}{c}\text { Tuber } \\
\text { length, cm }\end{array}$ \\
\hline $\mathrm{Zn}$ & Control & $249.6 \pm(46.3) \mathrm{a}$ & $7.8 \pm(2.0) \mathrm{a}$ & $38.3 \pm(11.1)$ & $72.4 \pm(1.8)$ & $2.0 \pm(0.2)$ & $8.5 \pm(0.5)$ \\
& 100 & $211.2 \pm(24.7) \mathrm{a}$ & $6.2 \pm(0.6) \mathrm{a}$ & $34.0 \pm(2.8)$ & $72.8 \pm(1.8)$ & $2.3 \pm(0.1)$ & $9.9 \pm(0.1)$ \\
& 500 & $220.6 \pm(15.5) \mathrm{a}$ & $7.6 \pm(1.0) \mathrm{a}$ & $31.8 \pm(4.0)$ & $74.0 \pm(2.4)$ & $2.2 \pm(0.1)$ & $9.7 \pm(0.2)$ \\
& 1,000 & $98.0 \pm(16.8) \mathrm{b}$ & $3.0 \pm(0.7) \mathrm{b}$ & $44.6 \pm(13.2)$ & $74.8 \pm(1.5)$ & $2.1 \pm(0.2)$ & $10.6 \pm(0.8)$ \\
$\mathrm{Cu}$ & Control & $256.3 \pm(26.3) \mathrm{a}$ & $7.3 \pm(1.8)$ & $41.2 \pm(8.9)$ & $66.5 \pm(2.5)$ & $2.3 \pm(0.2) \mathrm{b}$ & $9.4 \pm(0.7) \mathrm{a}$ \\
& 100 & $265.0 \pm(10.4) \mathrm{a}$ & $6.3 \pm(0.8)$ & $62.2 \pm(23.0)$ & $75.1 \pm(0.8)$ & $3.0 \pm(0.1) \mathrm{a}$ & $10.0 \pm(0.5) \mathrm{a}$ \\
& 500 & $255.7 \pm(10.6) \mathrm{a}$ & $7.3 \pm(0.6)$ & $36.9 \pm(3.1)$ & $70.5 \pm(2.1)$ & $2.4 \pm(0.1) \mathrm{b}$ & $8.9 \pm(0.5) \mathrm{b}$ \\
& 1,000 & $179.4 \pm(16.7) \mathrm{b}$ & $5.7 \pm(1.0)$ & $48.1 \pm(12.6)$ & $73.2 \pm(1.4)$ & $2.3 \pm(0.1) \mathrm{b}$ & $7.1 \pm(0.4) \mathrm{b}$ \\
$\mathrm{Ce}$ & Control & $139.2 \pm(63.8)$ & $5.0 \pm(2.0)$ & $23.6 \pm(5.4)$ & $65.0 \pm(1.7)$ & $2.0 \pm(0.3) \mathrm{b}$ & $5.8 \pm(1.0)$ \\
& 100 & $199.3 \pm(23.9)$ & $6.0 \pm(0.7)$ & $34.7 \pm(4.5)$ & $71.8 \pm(1.5)$ & $1.9 \pm(0.1) \mathrm{b}$ & $6.9 \pm(0.5)$ \\
& 500 & $212.9 \pm(36.7)$ & $4.6 \pm(0.5)$ & $51.0 \pm(11.8)$ & $72.3 \pm(2.3)$ & $2.6 \pm(0.2) \mathrm{ab}$ & $8.2 \pm(0.7)$ \\
& 1,000 & $185.0 \pm(23.6)$ & $3.7 \pm(0.8)$ & $51.0 \pm(9.3)$ & $71.1 \pm(2.4)$ & $2.7 \pm(0.2) \mathrm{a}$ & $6.7 \pm(0.5)$ \\
\hline
\end{tabular}

